\title{
Socio-economic status of the organic and conventional farming families of the selected agro-climatic zones of northern Karnataka
}

\author{
RAJESHWARI DESAI AND P.R. SUMANGALA
}

Received: 19.11.2014; Revised: 08.04.2015; Accepted: 23.04.2015

See end of the paper for authors' affiliations RAJESHWARI DESAI Extension Education Unit, Agricultural Research Station, GADAG (KARNATAKA) INDIA Email : rajmanohardesaiuas@gmail.com
ABSTRACT : Socio-economic status (SES) is a measure of a family's economic and social position in the society. The present study is designed to study the socio-economic status of the conventional and organic farming families of selected northern agro climatic zones of Karnataka. The total sample of the study comprised of 300 farm women. The socio-economic scale of Aggarwal et al. (2005) was used to assess the socio-economic status of the farming families. The organic farming families of all the three selected zones were comparatively better as compared to conventional farming families of the respective zone with respect to education, possession of land holdings, annual income, farming experience and livestock possession. Irrespective of the agro-climatic zones, very few households had pucca houses i.e., about 16 per cent of the organic and nine per cent of the conventional farming families had pucca houses. Slightly higher percentage of the organic farmers belonged to upper middle class as compared to conventional farmers in NDZ and NTZ while, cent per cent and majority of the organic and conventional farming families belonged to lower middle socio-economic status in NHZ. These results revealed that shift to organic production had positive impact on the socio-economic status of the farming in all the agro-climatic zones. This call for farmers' sensitization and encouragement to adopt organic farming that will not only cater for food and nutritional security but also quality life of farming families and sound management of the environment.

KEY WORDS: Organic farming, Conventional farming, Socio-economic status, Housing conditions

- HOW TO CITE THIS PAPER : Desai, Rajeshwari and Sumangala, P.R. (2015). Socio-economic status of the organic and conventional farming families of selected agro-climatic zones of northern Karnataka. Asian J. Home Sci., 10 (1) : 137-143. 